\title{
Livestock Grazing, Wildlife Habitat, and Rangeland Values
}

\author{
By Paul R. Krausman, David E. Naugle, Michael R. Frisina, \\ Rick Northrup, Vernon C. Bleich, William M. Block, \\ Mark C. Wallace, and Jeffrey D. Wright
}

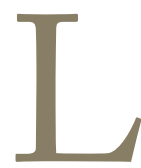

ivestock managers make and implement grazing management decisions to achieve a variety of objectives including livestock production, sustainable grazing, and wildlife habitat enhancement. Assessed values of grazing lands and ranches are often based on aesthetics and wildlife habitat or recreational values, which can exceed agricultural values, thus providing additional economic bases for effective grazing management. Perhaps more basic is the intention of many producers and managers to pass on the land in as good or better condition than when it was first acquired.

Grazing management plays a large role in the quality and extent of wildlife habitat. Livestock grazing is the most widespread land management practice in the world, affecting $70 \%$ of the land surface in the western United States. ${ }^{1}$ Chronic overgrazing is detrimental because it reduces primary productivity, impedes plant growth and survival, and alters species composition of the grasses, shrubs, and forbs that provide wildlife with food and cover. Past efforts to increase livestock production have also homogenized the natural variability of grasslands upon which wildlife populations depend. ${ }^{2}$

Some have questioned the value of rotational grazing based largely on vegetation and animal production while also recognizing a lack of conclusive research that might support other benefits, such as wildlife habitat enhancement. ${ }^{3}$ Conclusive experimental results showing a direct cause and effect between rotational grazing and enhancements to wildlife production or survival are indeed limited. This is more likely a product of the difficult nature of deriving this type of information with suitable rigor than it is an indication that rotational grazing does not influence certain wildlife values. Researching the effects of different grazing schemes with sufficient sample sizes at geographic scales reflective of a subpopulation's geographic extent can be demanding, particularly considering the overriding role that fluctuating weather events and other short-term factors can play in wildlife abundance.

The emergence of competing land uses that alter western rangelands are a sign of the times-and debates over livestock and wildlife values should be placed within this broader context. Ranchers and conservationists in the West realize that debates over grazing systems and stocking rates are of little consequence if rangelands continue to be lost or fragmented due to subdivision, farming, weed invasion, catastrophic wildfire, and energy development. However, impacts of domestic grazing that diminish land value via reduced range productivity and wildlife habitat quality can also lead to alternative land uses and habitat conversion. Maintaining the multiple values of western rangelands will require a shift from local to landscape conservation to match the scale of land use change that threatens grazing, rural ways of life, and wildlife habitat.

The future of western rangelands is in developing partnerships that help keep sustainable grazing the prevailing land use. Indeed, as rangelands are lost to other land uses, overlapping interests will make conservation partners out of otherwise odd associates-ranchers need open space for grazing and wildlife biologists, managers, and other conservationists want to maintain or enhance the wildlife values on working ranches.

In this paper, we review a representative sampling of scientific literature to document grazing impacts on wildlife and its habitat to better understand the roles of grazing strategies in wildlife habitat conservation. Further, we explore commonalities between grazing and conservation interests and provide a vision for advancing wildlife and habitat management and conservation.

\section{Synthesis of Grazing Impacts}

Grazing by domestic livestock can impact wildlife habitat in numerous ways. Composition and structure of a plant community are directly linked to qualities of wildlife habitat. As much as livestock grazing can affect vegetation characteristics, it will affect wildlife habitat structure and productivity. We consider these impacts at annual or short-term and long-term time scales.

Herbaceous vegetation provides hiding cover for a variety of grassland birds, amphibians, reptiles, small and large 
mammals, and others. Substantial annual consumption of herbaceous vegetation in native rangeland settings that leaves only remnant cover is detrimental to many wildlife species. Management for grassland songbirds typically requires a mosaic of grassland habitats because species preferences vary widely from tall and dense to short and sparse vegetation. ${ }^{4}$ Grazing can be used to diversify grassland habitats to benefit songbirds but overgrazing that leaves little vegetative cover is detrimental to songbird diversity. An abundance of short and sparse vegetation is beneficial to some species (e.g., chestnut-collared longspurs [Calcarius ornatus]) but would largely exclude others of management concern (grasshopper sparrow [Ammodramus savannarum]). For example, grasshopper sparrows in the southeastern United States had higher clutch sizes ( 4.5 vs. 3.9 young) and nest success (70\% vs. 25\%) in ungrazed than in grazed pastures. ${ }^{5}$ Moreover, invertebrate biomass was greater in ungrazed than in grazed areas, and vegetation had less litter, more shrubs, and shorter, less-dense vegetation in grazed than in ungrazed pastures. Most unsuccessful nests were depredated, and authors surmised that shorter, less-dense vegetation in grazed areas made it easer for predators to locate nests, whereas taller, denser vegetation in ungrazed areas provided greater concealment. ${ }^{6}$

Grazing of rangelands by domestic livestock, sometimes combined with other influences (e.g., fences, roads, structures), alters the structure and composition of rangelands, with resultant impacts to biodiversity and ecosystem function $^{7,8}$ that can alter the environment for predators and prey. For example, insects, an important food for many wildlife species, can be reduced in abundance as a result of reduced herbaceous cover due to domestic livestock grazing. ${ }^{7}$

Reduced productivity and survival of smaller insectivorous wildlife species may lower productivity for various species of carnivores. Alternatively, trophic cascades resulting from the elimination of top predators can have implications beyond the immediate ecosystem occupied by those carnivores. The results could be detrimental impacts to some species that may otherwise not have been preyed upon as a result of mesocarnivore release. ${ }^{9}$ Thus, a consequence of the reduction of many carnivores from rangelands in North America has had additional, but indirect, impacts to other species and different ecosystems than those from which carnivores in question were eliminated.

Domestic livestock grazing has also had a long-term impact on many native plant communities and the wildlife species adapted to these settings. Many native rangelands have experienced shifts in plant species composition due to persistent heavy grazing that leaves little ability for desirable perennial plants to reproduce (either by seed or vegetatively), resulting in a loss of favored plant species. ${ }^{10}$

Likewise, grazing lands over large expanses of the West have lost entire native plant communities due to invasion by exotic annual grasses and associated alteration of fire regimes. Invasion of these annual grasses has been facilitated by the absence of native vegetation, ${ }^{11}$ another effect of overgrazing that may have occurred over a century ago. The continued spread of exotic annual grasses is likely a function of vacant plant niches and increased fire frequency that further excludes native perennial vegetation. Many species dependent on sagebrush (Artemisia spp.) grasslands ${ }^{12}$ are thus directly impacted.

In similar fashion, the synergistic effects of planting with exotic crested wheatgrass (Agropyron cristatum) followed by grazing reduced small mammal abundance and locally extirpated all but one nesting bird species. ${ }^{13}$ Part of the problem could be solved by more aggressive measures to replace crested wheatgrass plantings with native perennial vegetation.

Riparian areas, considered to be among the most productive and critical habitats for wildlife, have a well-documented history of deterioration or destruction as a result of livestock's preference for these areas for grazing, watering, and loafing. ${ }^{14,15}$ Corresponding impacts to riparian wildlife are known; for example, livestock grazing in riparian ecosystems of western North America has been linked to decreased bird species diversity and abundance, ${ }^{16}$ and may influence bird populations by facilitating nest predation, possibly by increasing nest detection or through changes in predator assemblage. ${ }^{17}$ Similar examples are commonly available for fish. Trampling of riparian areas by domestic livestock destroyed redds (i.e., in-stream breeding sites) for the federally endangered bull trout (Salvelinos confluentus). ${ }^{18}$

Arthur Sampson, the "father of range management," writes, "The easiest way to overcome the deteriorating effect of premature grazing and overstocking, as well as of trampling, would be, of course, to eliminate grazing entirely. Obviously, however, such a procedure would be impracticable from the standpoint of the stock industry." ${ }^{19} \mathrm{He}$ then points out the means to solve the problem is in a scientific manner based on needs of the plants. Perhaps Sampson's reflection on this point is not wholly different from the current rotational grazing debate. A number of specific examples exist where rotational grazing has been successfully applied to meet the needs of vegetation and associated conservation objectives. We illustrate three case studies to provide an examination of how grazing management strategies have been used to achieve wildlife conservation objectives.

\section{Case Studies Documenting Benefits of Rotational Grazing}

Case Study 1: Grassland Birds in South Dakota

A comparison of three different types of rotational grazing systems at the Fort Pierre grasslands of South Dakota revealed some grazing strategies were more likely to fulfill standing cover requirements (455 kg/0.4047 ha; 1,000 pounds per acre) than others for prairie grouse (Tympanuchus spp.). ${ }^{20}$ The authors compared deferred rotation, restrotation, and winter-only grazing. Pastures that were grazed 
only in winter provided for the highest number of sharptailed grouse (Tympanuchus phasjanellur) and prairie-chicken (Tympanuchus spp.) nests and broods per 404.7 ha (1,000 acres). Rest-rotation grazing accommodated the second highest density of nests and broods for both of these species. Deferred rotation did not provide blocks of undisturbed cover available in the spring for nesting, which was reflected in the lowest density of nests and subsequent broods. Pastures managed under rest-rotation grazing, which had the highest cattle stocking rate of any system, produced approximately 10 times more nest-broods per 404.7 ha (1,000 acres) than pastures managed in a deferred rotation system. During the 5-year study, grouse followed the grazing rotation seeking the best herbaceous cover for nesting and rearing broods. Grouse preferred rest pastures for nesting that were at times $4.02 \mathrm{~km}$ (2.5 miles) from breeding leks. Brood movements were also related to cover height, and although quantitative data were not provided, the implication was that the heaviest cover available was sought by broods, especially during the heat of the day. In 1978, when vegetation conditions were good, movement by females was considerably less than in previous years as birds were never recorded more than $0.4 \mathrm{~km}(0.25$ miles $)$ from nest sites. Waterfowl nest data were also collected in this study, producing similar results among the three grazing systems. A key message from this study is the capacity for a grazing system to produce substantial wildlife while supporting the producer's economic needs.

\section{Case Study 2: Elk in Montana}

Planned grazing by cattle on elk winter ranges can be an effective way to enhance forage palatability. ${ }^{21}$ In 1984 a rotational grazing system was established to address forage conflicts between elk (Cervus elaphus) and livestock on Mount Haggin Wildlife Management Area in Montana. ${ }^{22}$ The system rotated rested pastures in a manner that maintained productive cover and forage for elk while enhancing native vegetation condition on all of the managed areas. A 2002 update of the Mount Haggin project revealed considerable riparian and grassland improvements from what had been managed as continuous season-long grazing prior to $1984 .{ }^{23}$ This is one of a number of examples in which conflicts over elk on private lands, availability of cover and forage, and adjacent landowner relations were improved using rotational grazing to fulfill a variety of conservation objectives in Montana. ${ }^{24,25}$

\section{Case Study 3: Small Mammals and Riparian Habitats}

Grazing exclosures were erected as wildlife habitat enhancement projects along riparian areas in Pennsylvania that had historically been continuously grazed by cattle. ${ }^{26}$ Researchers found within a short time frame (1-2 years of rest) that small mammal abundance and diversity (species richness) was approximately twice what they found on continuously grazed riparian areas. They speculated that improved stands of herbaceous vegetation provided enhanced combinations of food and cover, depending on the particular species of small mammal. Although this project did not specifically consider rotational grazing, the relatively quick response of small mammals to improved cover suggests the potential benefits of managing livestock in a manner that results in herbaceous cover improvements in riparian areas. Others similarly found that the grazing system on Mount Haggin Wildlife Management Area in Montana provided habitat for maintaining a substantial prey base of small mammals for hawks and owls. ${ }^{27}$ They concluded that a carefully designed grazing system would provide for substantially larger and more diverse small mammal populations than present under continuous season-long grazing.

In each case study the temporary or permanent partitioning of habitats using fenced pastures provided benefits to wildlife. Seasonal deferment and year-long rest provided effective habitat for very different wildlife species. Others have pointed to the value of using pastures as a mechanism for controlling livestock and achieving wildlife habitat objectives. ${ }^{28}$ In some situations the pasture being grazed by livestock may provide the habitat component desired by a wild species; for example, young greater sandhill cranes (Grus canadensis tabidu) in search of invertebrates preferred the grazed pasture within a rest-rotation system. ${ }^{29}$ Other investigators reached similar conclusions and provided a graphic of grazing treatments and their potential benefits to wildlife, including deferment and rest. ${ }^{30}$

\section{Analysis and Recommendations}

Our synthesis, although limited by space, clearly documents the overwhelming and negative impacts that poorly managed or inappropriate livestock grazing can have on wildlife populations and their associated habitats. Results are highly variable because ecosystems differ widely in their adaptation to grazing. The severity of impacts is directly related to environmental gradients and grazing regimes, both notoriously difficult to quantify. However, habitat needs of many species are well known and these requirements provide the "biological sideboards" necessary to develop guidance for grazing strategies for maintaining or enhancing wildlife populations. Food, cover, and space are indisputable habitat needs. ${ }^{31}$ Domestic livestock grazing can directly affect one or more of these elements. The question of rotational vs. continuous grazing can be reduced to managing livestock in a manner that supports these basic habitat elements while maintaining native plant community integrity-the same plant communities to which native wildlife have adapted.

Continuous grazing at moderate stocking levels can result in long-term deterioration of important plant communities, including upland ${ }^{32}$ and riparian areas. ${ }^{14}$ Although it may be possible to maintain native rangeland integrity using light stocking levels, we question the economic viability of this approach for most traditional livestock producers. ${ }^{33} \mathrm{We}$ also 
question the ability to maintain quality habitat features even under light stocking for areas where livestock prefer to graze. ${ }^{14,32}$

Grazing is not universally "bad" or "good" for wildliferather, it has positive or negative effects depending on current and historic timing and intensity of grazing, soil conditions, precipitation, plant communities, and specific habitat features under consideration. The literature does not provide a comprehensive review of the benefits of continuous vs. rotational grazing to wildlife populations. Replicated experiments to further document wildlife response to different grazing systems should be a focus of research to help guide landowners and public-land managers to practices that are beneficial to wildlife and economically viable to producers. But the appropriate response is not a call for more research; rather, the appropriate response is to ascertain what can be done now in light of uncertainty to sustain wildlife populations that depend on grassland and shrubland habitats. ${ }^{34}$

We propose that the alternative to continuous grazing is to develop grazing strategies that are appropriately stocked and are managed to provide blocks of undisturbed cover at times that allow for plant reproduction and energy storage and wildlife reproduction and survival. We recommend that producers and managers establish grazing management systems that help to achieve long-term native habitat conservation objectives while using grazing treatments that provide for basic cover and food needs of wildlife species. The most practical way to accomplish this may be through carefully planned grazing systems that use pastures as a means to control livestock distribution and timing of grazing. Grazing rotations can achieve short- and long-term conservation objectives. When wildlife habitat needs are considered in the pasture layout, pastures scheduled for rest and deferment can serve as high-quality habitat areas providing food and cover for wildlife as other pastures are being grazed, sometimes intensively, by livestock. Briske et $\mathrm{al}^{3}{ }^{3}$ similarly acknowledged the long-term benefits of lengthy rest coinciding with plant growth as contributing to the sustainability and recovery of grazed ecosystems. Carefully planned grazing rotations can therefore ensure maintaining native habitats that are also functional for an abundance and diversity of wildlife.

Maintaining rangeland function requires a shift from local to landscape conservation to match the scale of land use change that threatens grazing, rural ways of life, and wildlife populations. ${ }^{35}$ Rotational grazing is more likely to help managers achieve wildlife habitat objectives than continuous grazing because, through grazing treatments, key wildlife habitat components can be assured on the landscape from year to year. That is, rotational grazing systems may be more useful than continuous systems for providing necessary habitat elements (food and cover) in specific locations at specific times. Continuous grazing at light stocking rates seems to leave to chance the possibility of achieving specific wildlife objectives in any given area.

\section{References}

1. Fleischner, T. L. 1994. Ecological costs of livestock grazing in western North America. Conservation Biology 8:629-644.

2. Fuhlendorf, S. D., And D. M. Engle. 2001. Restoring heterogeneity and rangelands: ecosystem management based on evolutionary grazing patterns. BioScience 51:625-632.

3. Briske, D. D., J. D. Dener, J. R. Brown, S. D. Fuhlendorf, W. R. Teague, K. M. Havstad, R. L. Gillen, A. J. Ash, and W. D. Williams. 2008. Rotational grazing on rangelands: reconciliation of perception and experimental evidence. Rangeland Ecology and Management 61:3-17.

4. Fuhlendorf, S. D., W. C. Harrell, D. M. Engle, R. G. Hamilton, C. A. Davis, And D. M. Leslie, Jr. 2006. Should heterogeneity be the basis for conservation? Grassland bird response to fire and grazing. Ecological Applications 16:17061716.

5. Davis, S. K. 2005. Nest-site selection patterns and the influence of vegetation on nest survival of mixed-grass prairie passerines. Condor 107:605-616.

6. Sutter, B., and G. Ritchison. 2005. Effects of grazing on vegetation structure, prey availability, and reproductive success of grasshopper sparrows. Journal of Field Ornithology 76: 345-351.

7. Rambo, J. L., and S. H. Faeth. 1999. Effect of vertebrate grazing on plant and insect community structure. Conservation Biology 13:1047-1054.

8. Blaum, N., E. Rossmanith, A. Popp, and F. Jeltsch. 2007. Shrub encroachment affects mammalian carnivore abundance and species richness in semiarid rangelands. Acta Oecologica 31:86-92.

9. Berger, K. M., E. M. Gese, and J. Berger. 2008. Indirect effects and traditional trophic cascades: a test involving wolves, coyotes, and pronghorn. Ecology 89:818-828.

10. SAvory, A. 1988. Holistic resource management. Washington, DC, USA: Island Press. 545 p.

11. Chambers, J. C., B. A. Roundy, R. R. Blank, S. E. Meyer, and A. Whittaker. 2007. What makes Great Basin sagebrush ecosystems invasible by Bromus tectorum? Ecological Monographs 77:117-145.

12. Welch, B. L. 2005. Big sagebrush: a sea fragmented into lakes, ponds and puddles. Fort Collins, CO, USA: US Department of Agriculture, Forest Service, Rocky Mountain Research Station. General Technical Report RMRS-GTR-144. 210 p.

13. Reynolds, T. D., And C. H. Trost. 1980. The response of native vertebrate populations to created wheatgrass planting and grazing by sheep. Journal of Range Management 33: 122-125.

14. Kauffman, J. B., and W. C. Krueger. 1984. Livestock impacts on riparian plant communities and stream-side management implications, a review. Journal of Range Management 37:430-437.

15. Chaney, E., W. Elmore, And W. S. Platts. 1990. Livestock grazing on western riparian areas. Eagle, ID, USA: Northwest Resource Information Center, Inc., for US Environmental Protection Agency. 45 p.

16. Mosconi, S. L., And R. L. Hutto. 1982. The effect of grazing on the land birds of a western Montana riparian habitat. In: J. M. Peek and P. D. Dalke [EDs.]. Proceedings of the Wildlife Livestock Relationships Symposium. Moscow, ID, USA: 
University of Idaho, Forestry, Wildlife and Range Experiment Station. p. 221-233.

17. Martin, T. G., and S. McIntyre. 2007. Impacts of livestock grazing and tree clearing on birds of woodland and riparian habitats. Conservation Biology 21:504-514.

18. Gregory, J. S., And B. L. Gamett. 2009. Cattle trampling of simulated bull trout redds. North American Journal of Fisheries Management 29:361-366.

19. Sampson, A. 1914. Natural revegetation of range lands based upon growth requirements and life history of the vegetation. Journal of Agricultural Research 3:93-170.

20. Rice, L. A., And A. V. Carter. 1982. Evaluation of South Dakota grassland management practices as they affect prairie chicken populations, 1974-1978. Pierre, SD, USA: South Dakota Department of Game Fish and Parks. Completion report 84-11. $25 \mathrm{p}$.

21. Frisina, M. R. 1992. Elk habitat use within a rest-rotation grazing system. Rangelands 14:93-96.

22. Grover, K. E., And M. J. Thompson. 1986. Factors influencing spring feed site selection by elk in the Elkhorn Mountains, Montana. Journal of Wildlife Management 50:466-470.

23. Frisina, M. R., And R. B. Keigley. 2004. Habitat changes Mount Haggin Wildlife Management Area. Rangelands 26: 3-13.

24. Frisina, M. R., and F. G. Morin. 1991. Grazing private and public land to improve the Fleecer elk winter range. Rangelands 13:291-294.

25. Alt, K. L., M. R. Frisina, And F. J. King. 1992. Coordinated management of elk and cattle, a perspective: Wall Creek Wildlife Management Area. Rangelands 14:12-15.

26. Guiliano, W. M., and S. D. Homyack. 2004. Shortterm grazing exclusion effects on riparian small mammal communities. Journal of Range Management 57:346-350.

27. Douglass, R. J., and M. R. Frisina. 1993. Mice and management on Mount Haggin Wildlife Management Area. Rangelands 15:8-12.

28. ENG, R. L., AND R. J. MAскIE. 1982. Integrating grazing-range management practices with management of major wildlife species on rangeland in northcentral Montana. In: Western Proceedings 62nd Annual Conference of the Western Association of Fish and Wildlife Agencies; 19-22 July 1982; Las Vegas, NV, USA. p. 112-119.
29. Frisina, M. R., And J. E. Canfield. 1987. A plan for inventory and management of greater sandhill cranes on the Mount Haggin Wildlife Management Area, Montana. Proceedings of the Montana Academy of Science 47:21-26.

30. Payne, N. F., and F. C. Bryant. 1994. Techniques for wildlife habitat management of uplands. New York, NY, USA: McGraw-Hill. 840 p.

31. Krausman, P. R. 2002. Introduction to wildlife management. The basics. Upper Saddle River, NJ, USA: Prentice Hall. $478 \mathrm{p}$.

32. Teague, W. R. and S. L. Dowhower. 2003. Patch dynamics under rotational and continuous grazing management in large, heterogeneous paddocks. Journal of Arid Environments 53:211-229.

33. Holecheck, J. L., H. Gomez, F. Molinar, and D. Galt. 1999. Grazing studies: what we've learned. Rangelands 21: $12-16$.

34. Sayre, N. F. 2009. Bad abstractions: response to Sullivan. Conservation Biology 23:1050-1052.

35. Williams, C. K., F. S. Guthery, R. D. Applegate, and M. J. Peterson. 2004. The northern bobwhite decline: scaling our management for the twenty-first century. Wildlife Society Bulletin 32:861-869.

Authors are Boone and Crockett Professor of Wildlife, Wildlife Biology Program, 32 Campus Dr, University of Montana, Missoula, MT 59812, USA, paul.krausman@umontana.edu (Krausman); Associate Professor (Naugle) and Boone and Crockett Fellow (Wright), Wildlife Biology Program, 32 Campus Dr, University of Montana, Missoula, MT 59812, USA; Range/Habitat Coordinator Montana Fish, Wildlife and Parks, and Adjunct Professor of Range Management, Montana State University, Bozeman Campus, 1330 W Gold St, Butte, MT 59701, USA (Frisina); Game Bird Coordinator, Montana Fish, Wildlife and Parks, PO Box 200701, Helena, MT 59620, USA (Northrup); Adjunct Professor, Dept of Biological Sciences, Idaho State University, Pocatello, ID 83209, USA (Bleich); Wildlife and Terrestrial Ecosystems Program Leader, US Forest Service, Rocky Mountain Research Station, 2500 S Pine Knoll Dr, Flagstaff, AZ 86001, USA (Block); and Associate Professor, Dept of Natural Resources Management, Texas Tech University, Lubbock, TX 79409, USA (Wallace). 